\title{
KEBIJAKAN PENCEGAHAN GERAKAN ISIS DI INDONESIA: PENDEKATAN SYSTEM DYNAMICS
}

\author{
Asep Setiawan \\ Dosen Prodi Hubungan Internasional Universitas Muhammadiyah Jakarta \\ asepsetia@gmail.com
}

\begin{abstract}
Abstrak
Negara Slam Irak dan Suriah (ISIS) meluncurkan sebuah kampanye untuk merekrut pengikut baru di seluruh dunia. ISIS menggunakan pola rekrutmen langsung dan tidak langsung dengan media sosial yang disebut cyber jihad dan jaringannya di banyak negara. Dengan pendekatan System Dynamics, artikel tersebut mencoba memahami bagaimana pemerintah Indonesia menanggapi kebijakan agresif ISIS untuk memperluas pengaruhnya dan pengikutnya. Ini menunjukkan bahwa jika Indonesia tidak bertindak untuk mencegah ekspansi ISIS, negara tersebut akan menjadi sasaran lebih lanjut gerakan radikal ini. Pemerintah Indonesia menggunakan program deradikalisasi dan operasi militer akan memberi dampak untuk meminimalkan pengaruh dan perekrutan ISIS.
\end{abstract}

Kata Kunci: ISIS, rekrutmen, Indonesia, Pendekatan System Dynamics, Iraq, Syria.

\begin{abstract}
slamic State of Iraq and Syria (ISIS) launch a campaign to recruit new followers around the world. ISIS uses direct and indirect pattern of recruitment with social media which is called cyber jihad and its network in many countries. With system dynamics approach, the article tries to understand how Indonesia's government to response ISIS aggressive policy to expand its influence and its followers. It shows that if Indonesia does not act to prevent ISIS expansion, the country will be further target of this radical movement. Indonesia government employs deradicalisation program and military operation will give impact to minimize influence and recruitment ISIS.
\end{abstract}

Keywords: ISIS, Recruitment, Indonesia, System Dynamics Approach, Iraq, Syria.

\section{Pendahuluan}

Negara Islam di Irak dan Suriah yang disebutIslamic State of Iraq and Syria (ISIS) merupakan kelompok radikal Islam yang saat ini menguasai sebagian dari Irak dan
Suriah. Kota-kota penting yang pernah dikuasaiISIS ini antara lain kota kedua terbesar di Irak, Mosul kemudian juga kota lainnya yang merupakan basis pendukung Saddam Hussein, Tikrit dan sebagian dari Anbar (Patrick Cockburn, 2015). ahkan ISIS pernah 
menguasai Ramadi yang jaraknya sekitar 100 kilometer dari Baghdad, ibu kota Irak. Selain memiliki kekuasaan di Irak, ISIS juga memiliki wilayah di Suriah terutama di wilayah timur negeri ini.

Tanggal 29 Juni 2014 ISIS mengklaim dirinya sebagai Kekhalifahan Islam dan menyerukan umat Islam di dunia untuk menyatakan kesetiaannya kepada mereka. Dengan deklarasi seperti ini ISIS melakukan kampanye rekruitmen besar-besaran terutama melalui internet dan media sosial serta secara langsung melalui jaringan kelompok radikal. Kampanye inilah yang membuat dunia khawatir termasuk Indonesia. Dengan kampanye agresif ini mereka melakukan perekrutan terbuka kepada calon-calon pendukungnya dari seluruh dunia baik secara langsung maupun tidak langsung. Rekrutmen ini telah mendorong munculnya berbagai aksi terorisme di berbagai negara termasuk Indonesia.

Untuk membahas kebijakan Indonesia dalam menghadapi kamanye ISIS dan implikasinya berupa aksiaksi teror akan dilakukan melalui pendekatan system dinamics. Model ini dijelaskan dalam (Muhammad
Tasrif. 2016). Pendekatan ini melalui beberapa tahap yakni:

\section{Problem Identification and} definition

2. System Conceptualization

3. Model formulation

4. Analysis of model behaviour

5. Model Evaluation

6. Policy Analysis

7. Model use or implementation

Sebagian tahapan itu akan dipaparkan dalam tulisan ini. Penulis lalu akan membuat model system dynamics kebijakan Indonesia dalam menghadapi rekrutmen ISIS untuk mencegah meluasnya pendukung ISIS, mencegah tindak terorisme di Indonesia serta mencegah pengikut dari Indonesia pindah ke Suriah dan Irak.

\section{Identifikasi Masalah}

Kampanye ISIS sejak Juni 2014 telah menyebabkan tumbuhnya pengikut yang ada di Indonesia dan ratusan orang pindah untuk bergabung dengan ISIS di Irak dan Suriah. Keberhasilan kampanye ISIS ini menimbulkan aksi terorisme baru di Indonesia seperti berlangsung Januari 2016 dan pindahnya ratusan orang bahkan 
mungkin lebih ke wilayah Timur Tengah.

Dasar kampanye rekrutmen ISIS ini adalah ideologi jihadi salafi yang berbasis kepada paham Wahabi. ISIS sendiri mulai terbentuk tahun 2003 dengan akar yang bisa dilacak ke kelompok Al Qaeda di Irak (AQI) (Jessica Stern and J.M. Berger. 2015: Jessica Stern and J.M. Berger. 2015:h.16). Pecahan Al Qaeda ini mengincar tidak hanya kelompok Syiah di Irak tetapi juga suku-suku Suni yang bertentangan dengan mereka.

Namun munculnya ISIS ke permukaan ini sendiri berakar dari kekacauan yang terjadi di Suriah dan Irak. Di Irak, pemerintahan PM Nouri Al Maliki yang pro Syiah menyebabkan kaum Sunni menjadi terkucil. Persoalan internal yang disebabkan sikap Nouri Al Maliki inilah yang menyebabkan suku-suku yang menganut Sunni menjadi terdesak, termasuk di dalamnya para perwira militer loyalis Saddam.

Dengan latar belakang kekacauan politik yang berkelanjutan di Suriah dan Irak inilah, ISIS seperti alternatif perlindungan bagi warga yang terjepit antara tekanan Al Maliki dengan tekanan kelompok
militan.Secara singkat dapat dikatakan, ideologi dari ISIS adalah Salafi Jihadi (Cole Bunzel. 2015). Ideologi ini sama dengan Al Qaeda dan Taliban. Bedanya dalam pendekatanya mengenai penegakan Khalifah Islam. Kelompok Jabhat Al Nusra, kelompok Al Qaeda di dalam perang sipil Suriah, yakin bahwa rencana jangka panjangnya menegakkan Kekhalifahan namun mereka berpendapat waktunya belum tepat.

Proses lahirnya ISIS sampai mendeklarasikan sebagai Kekhalifahan tidak lepas dari pemikiran yang berkembang di Timur Tengah yang berakar dari pemikiran Wahabi. Paham Wahabi dibangun oleh Muhammad bin Abdul Wahab 1115-1206 $\mathrm{H}$ atau 1703-1792M, seorang ulama asal Uyainah, Najd, di belahan timur Jazirah Arab. Ayahnya, 'Abdul Wahab adalah hakim (qadi) pengikut madzhab Ahmad ibn Hanbal. Karena itu istilah Salafisme atau paham Salafi sering diartikan secara bertukar ganti dengan "wahabi”.

Selain mengikuti Muhammad bin Abdul Wahhab, mereka juga mengikuti Ibnu Taimiyah yang hidup di abad ketujuh hijriyah. Ulama yang 
lebih dahulu dari Abd Wahhab dalam mendakwahkan puritanisme. Karena itu para pegiat dakwah Salafi pada umumnya menaruh hormat yang tinggi kepada Ibnu Taimiyyah.

Sekalipun beberapa ulama Mesir pada abad ke-19 yaitu Muhammad Abduh, Jamaluddin alAfghani, dan Rasyid Ridha dikenal sebagai pegiat puritanisme, tetapi sebagian kaum Salafi menolak pemikiran mereka, karena mereka menerima, bahkan menganjurkan umat Islam melakukan rasionalisasi pemikiran dan menerima "modernism".

Menurut Fahrur Razi dalam artikel "Global Salafi Jihadi Tantangan Masa Depan Islam Indonesia" , Wahabi berganti baju menjadi Salafi atau terkadang Ahl alSunnah yang seringnya tanpa diikuti dengan kata wa al-Jama'ah karena mareka risih disebut Wahabi. Selain itu, mereka juga mengalami banyak kegagalan dalam dakwahnya karena penisbatan tersebut.

Roel Meijer dalam Global Salafism: Islam's New Religious Movement dikutip Fahrur Razi menyebutkan ada empat doktrin Salafi. Pertama, program Wahabisme untuk kembali kepada sumber- sumber pokok Islam (al-Qur'an dan Hadist), sedang secara faktual mengikuti madzhab Hanbali.Kedua, regulasi hubungan antara orang mukmin dan bukan mukmin. Kontribusi Wahabisme terhadap Salafisme adalah perlakuan keras terhadap orang asing dan sekte-sekte yang non-Wahabi. Di sinilah muncul konsep ajaran al-Wala' wa al-Bara' (kesetiaan dan penolakan) atau antara orang mukmin dan bukan mukmin. Wilayah non Wahabi disebut sebagai negara orang-orang musyrik (bilad al-musyrikin). Hal ini dapat digunakan untuk memahami perang dengan kerajaan Ottoman dan invasi ikhwan (pasukan khusus Wahabi) ke Iraq.

Ketiga, tema Wahabi yang mempengaruhi Salafisme dan telah menjadikannya radikal adalah penolakannya terhadap syi'ism sebagai bid'ah dengan dua alasan:

$$
\text { orang-orang Syi'ah }
$$
mengkultuskan imam dan,

(2) orang-orang Syi'ah menolak tiga Khulafa' Rashidun (632-661) dan karenanya orangorang Syi'ah menolak sahabat Nabi dan otentisitas Hadist yang merupakan dasar doktrin Wahabi.

Keempat, ambiguitas

Wahabisme yang diwariskan kepada 
Salafisme modern adalah pada praktik hisab, yakni al-amr bi al-ma'ruf wa al-nahy 'an almunkar. Meskipun praktik ini berlangsung lama dan telah eksis sejak masa dinasti Abbasiyah (750-1258M) dan dinyatakan oleh Ibnu Taimiyyah sebagai bentuk puncak jihad, hal tersebut dipertahankan oleh Wahabisme untuk menegaskan sikap moral kerasnya terhadap masyarakat dan meluruskan deviasi seperti merokok, memuja tempat keramat, dan bentuk-bentuk lain yang tergolong perbuatan syirik.

Gerakan Salafi ini memfokuskan kepada studi keagamaan dan berdakwah sebagai cara untuk menciptakan masyarakat dan negara Islam. Namun dalam gerakan Salafi ini muncul faksi ekstrem yang disebut Salafiyya Jihadiyya (Jihad Salafi). Pandangan ideologis yang mempengaruhi perkembangan Salafi muncul dari Sayyid Qutb (1906-1966) yang menginspirasi perlawanan dengan jalan keras.

Puncak dari karakter ideologi ISIS ini mengumumkan terbentuknya Khilafah Islam 29 Juni 2014 sebagai perlawanan terhadap dunia yang tidak mendasarkan kehidupannya pada ajaran Islam. Ideologi ISIS ini juga berangkat dari paham Sunni yang mendasarkan kepada kehidupan kaum Salafi. Oleh karena itulah kebangkitan ISIS menimbulkan persoalan baru relasi mereka dengan kelompok Syiah. Dari sikap-sikap ISIS terlihat mereka sangat kejam dalam memperlakukan kaum Syiah dan kelompok Sunni yang tidak sejalan. Selain itu pendukung ISIS melakukan aksi merusak peninggalan peradaban lama yang dianggap musyrik sebagai refleksi paham yang berakar dari Wahabisme.

Salah satu karakteristik ISIS dalam berkampanye untuk merekrut dan mencari pengikutnya adalah menggunakan saluran modern teknologi informasi (Adam Hoffman and Yoram Scheitzer. 2015). Berbagai cara dilakukan untuk melakukan kampanye secara global melalui saluran internet. Sejumlah perangkat media sosial mulai dari Twitter, Facebook, Tumblr, Instagram sampai dengan Youtube digunakan secara efektif sehingga mempengaruhi individu dan gerakan Islam di sejumlah negara termasuk di Indonesia. Dengan $80 \%$ dari 250 juta orang Indonesia pengguna internet terhubung ke media sosial maka 
menjadi sasaran empuk Cyber Army ISIS (Francisco Galamas. 2015:h.10).

ISIS melakukan propaganda melalui majalah berbahasa Inggris yang disebut dengan Dabiq serta memproduksi film berkualitas tinggi yang disalurkan melalui You Tube, Twitter dan berbagai situs internet. Sebuah informasi menyebutkan ISIS memproduksi 90.000 Twitter setiap hari. Bahkan sebuah studi menyebutkan pendukung ISIS mengoperasikan 46.000 akun Twitter independen.

Cyber Jihad ISIS ini merupakan bagian dari strategi militer dan perluasan wilayah. Pertama, penggunaan media sosial dan khususnya maniplasi dalam jaringan media sosial seperti menggunakan aplikasi Dawn of Glad Tiding mampu memperbesar dimensi organisasi ini serta menimbulkan efek perang psikologis. Kombinasi antara tingginya volume di media sosial dengan gambar dan video menakutkan menimbulkan efek cemas dari musuh ISIS.

Kedua untuk meningkatkan peluang merekrut, ISIS menggunakan media sosial sebagai alat pemasaran bahkan dirancang khusus dengan target individual. John Horgan dikutip
Adam Hoffman pakar psikologi forensik mencatat bahwa peluang untuk merekrut kaum muda di tengah tingginya popularitas media sosial adalah unik dan sangat besar dalam sejarah terorisme. Cyber Jihad ISIS ini memberikan dampak mempercepat rekrutmen milisi asing untuk bergabung dan mendorong serangan teroris di Barat oleh perseorangan yang disebut sebagai "lone wolves".

Anggota dan pendukung kelompok radikal Indonesia merespons kampanye ISIS. Mereka tidak hanya menanggapi kampanye itu malah melakukan kampanye susulan di Indonesia melalui jaringan internet dan media sosial dan juga secara langsung melalui jaringan kelompok radikal dan simpatisannya.Secara langsung misalnya dengan mengadakan apa yang disebut Tabligh Akbar seperti terjadi di Masjid Madyo Mangun Karso Semarang bulan Januari 2015.

Kampanye perekrutan secara online dilakukan melalui media sosial seperti Facebook, YouTube, Twitter dan sejumlah website. Situs voaislam.com dan damailahindonesiaku.com sebagai salah satu contoh alat penyebaran radikalisme dari ISIS. Dampak dari 
kampanye ISIS itu terlihat misalnya pada Februari 2015, sejumlah kelompok Islam yang berjumlah ratusan yang menamakan diri sebagai Forum Aktivis Syariat Islam (FAKSI) menyatakan bai'atnya kepada amir ISIS. Salah atu bunyi bai'at yang dibacakan ustadz Abu Sholih atTamorowi menyatakan,

"Demi Allah, sungguh kami dan seluruh kaum muslimin bernahagia dengan Daulah Islam Iraq dan Syam (ISIS) yang insya alloh akan menjadi cikal bakal Khilafah Islamiyah Ala Minhajin Nibuwwah" (http://www.csrc.or.id).

Setelah ISIS mendeklarasikan khilafah Islamiyah pada 29 Juni 2014, maka seminggu kemudian ratusan orang dengan bendera FAKSI tangal 6 Juli 2014 menyatakan baiat nya kepada kekhilafahan ISIS. Sebagain besar peserta berasal dari beberapa daerah di Jawa Barat, banten, Lampung dan Riau. Dalam baiat yang dipimpin Abu Zakariyya mereka menyatakan

" Saya berbaiat kepada amirul mukminin Abu Bakar al Baghdadi al Quraysi untuk mendengar dan taat kepada kondisi susah dan mudah. Pada konsisi diam dan malas. Dan walaupun hak kami ditelantarkan. Serta saya, tidak akan merampas kekuasaan dari pemiliknya kecuali saya melihat kekafiran yang nyata, yang saya memiliki dalil yang nyata di dalamnya dari Allah. Allahu Akbar"

Kemudian , sejumlah ormas Islam di Solo, Jakarta, Bekasi, dan Bima juga menyatakan baiatnya secara demonstratif. Di Bekasi, deklarasi dilakukan oleh perkumpulan yang menamakan diri Kongres Umat Islam. Dukungan mereka itu terkait dengan akar ideologi ISIS yang bersifat radikal yang mirip dengan sejumlah kelompok radikal di Indonesia. yakni pembentukan kekhilafahan Islam. Beberapa aktifis yang berperan penting dalam aksi dukungan itu berasal dari organisasi Jamaah Anshorut Tauhid (JAT), Salafi Jihadi Aman Abdurrahman, dan beberapa kelompok kecil yang lain. Abu Bakar Baasyir dari LP Nusakambangan dilaporkan juga memberikan baiat nya kepada kekhilafahan Islamiyah bentukan ISIS. Belakangan pimpinan Gerakan Reformis Islam (Garis) Cianjur, menyatakan diri sebagai Presiden ISIS Indonesia.

Jumlah yang bergabung dengan ISIS bertambah dari tahun ke tahun. Tahun 2014, diperkirakan 60 orang Indonesia bertempur bersama ISIS. Tahun 2016, pemerintah Indonesia menyebut 700 orang ikut 
ISIS (Hardin Lang and Muath Al Wari, 2016). Diantara penambahan jumlah orang itu berasal dari pekerja migran dan mahasiswa di Timur Tengah. Namun demikian sebuah kajian menyebutkan bahwa sejumlah milisi itu berasal dari mahasiswa Indonesia di Yaman dan Pakistan. Ratusan orang Indonesia itu adalah bagian dari milisi asing ISIS yang jumlahnya mencapai 27.000 sampai 31.000 berasal dari 86 negara.

$$
\text { Laporan lain dari }
$$

gatestoneinstitute.orgmenyebutkan

ISIS telah merekrut setidaknya 500 orang Indonesia sampai akhir tahun 2014 (George Phillips, 2015). Namun menurut Greg Fealy jumlah persis orang Indonesia yang bergabung kepada ISIS tidak diketahui persis (Greg Fealy and John Funston. 2016). Disebutkan orang Indonesia dan Malaysia berkisar dalam jumlah 300 sampai 450 orang datang ke Irak dan Suriah, diduga separuh dari jumlah itu bergabung dengan ISIS.

Menurut Greg Fealy, data yang paling bisa dipercaya berasal dari Detasemen 88 yang bulan Juni 2015 menyebutkan telah merangkum adanya 202 kasus orang Indonesia di Timur Tengah. The Institute of Policy and Conflict (IPAC) di Jakarta yakin bahwa terdapat 250 sampai 300 jihadis yang bertempur dengan ISIS. Sementara Kepala BNPT Saud Usman Nasution mengungkapkan bahwa kelompok-kelompok radikalis semakin masif menyebarkan kontenkonten radikal di media online. Usman mengharap kontribusi para pegiat internet, media social dan bloger untuk melawan konten-konten radikal di dunia maya dengan konten-konten positif (kiblat.net, 2015).

Wilayah ISIS yang dikuasai sampai tahun 2016 mulai menyusut sejak 2014 karena terjadi gerakan anti ISIS dari koalisi pimpinan Amerika Serikat seperti terlihat di peta berikut (bbc.com, 2016):

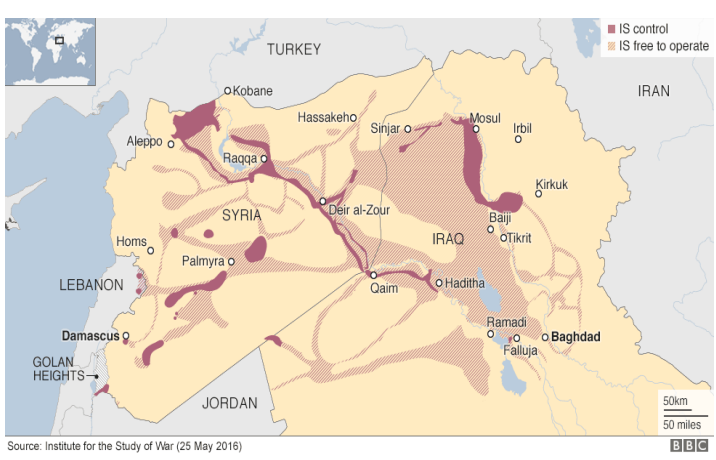

Peta itu menunjukkan bahwa wilayah ISIS tersebar antara Irak dan Suriah namun sebagian sudah tidak dikuasainya lagi karena mendapat tantangan dari pemerintah Irak dan Suriah serta koalisi 
Dalam pesan rektrutmennya mellaui media social, buku/majalah dan langsung lewat jaringan kelompok radikal, ISIS mengajukan lima tahap yakni pertama, seruan agar yang direkrut untuk hijrah ke kawasan ISIS di Suriah dan Irak serta medan pertempuran lainnya. Kedua, bergabung dengan jamaah dan ikut berlatih. Ketiga, melakukan destabilisasi pemerintah pusat dengan melakukan terorisme dan perang gerilya. Tahap keempat, penegakan proto-state (bakal negara) setelah tentara pemerintah dan dikalahkan. Tahap kelima, penegakan keemiran Islam atau jika di Suriah/Irak menegakan kekhalifahan (Michael Ryan, 2015).

Pemerintah Indonesia melakukan kebijakan pembendungan pengaruh ISIS sejak 2014 setelah terjadi penampakan pendukung ISIS di Indonesia. Dalam gambar yang dikutip oleh gatestoneinstitute.org tampak bahwa sebelum ada larangan keras dari pemerintah Indonesia untuk menyebarkan paham ISIS, kelompok ini telah melakukan kampanye secara terbuka. Gambar yang terekam di Bundaran Hotel Indonesia, Jakarta Pusat menunjukkan bahwa dukungan sudah muncul di Indonesia terhadap kehadiran ISIS di Timur Tengah (George Phillips, 2015).

Kampanye terbuka ini juga menunjukkan bahwa ideologi ISIS menjadi daya tarik sebagian anggota masyarakat di Indonesia. Pernyataan yang diajukan dalam spanduk berbicara banyak mengenai dukungan terhadap ISIS.

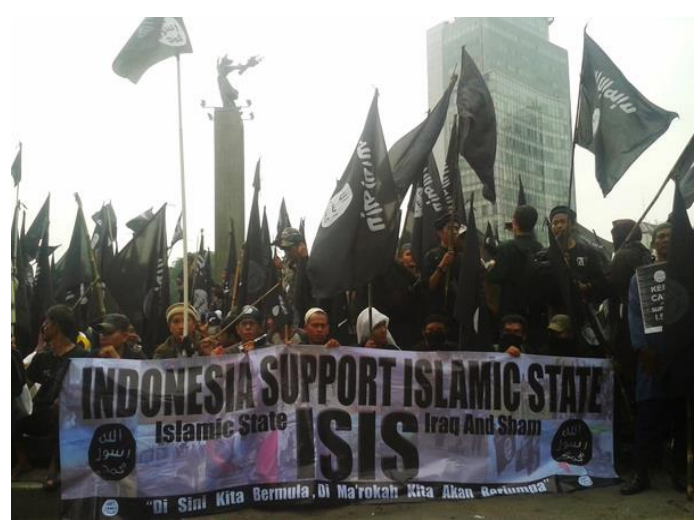

Serangan di pusat kota Jakarta di kawasan Thamrin menunjukkan kampanye ISIS berdampak langsung. Para penyerang ini melakukan tindakannya dengan mengincar simbol Amerika Serikat yakni kafe Starbucks dan simbol kekuatan Indonesia yakni polisi. Tindakan para peneror ini yang dapat dilumpuhkan oleh apparat keamanan Indonesia tampaknya menunjukkan jati diri sebagai para pendukung ISIS yang memberikan pesan kepada dunia. Para pelaku dengan terang-terangan melakukan 
serangan itu di tengah sorotan media massa.

Serangan teror ini menjadi salah satu identitas kehadiran ISIS di Indonesia. Hal ini terungkap ketika pihak keamanan Indonesia mengidentifikasi para penyerang yang beraksi 14 Januari 2016 telah menerima intruksi dari Bahrun Naim, warga Indonesia yang berkampanye melalui You Tube mengajak bergabung dengan ISIS di Suriah (Kirk D'Souza, 2016). Dampak ISIS di Indonesia juga tampak dengan kekuatan kelompok Santoso yang didukung jaringan internasional di Poso, Sulawesi Tengah. Pemerintah menduga mereka adalah bagian dari Mujahidin Indonesia Timur yang menyatakan setia kepada ISIS.

Setelah ajakan ISIS semakin marak bahkan dalam video yang dipasang di You Tube, barulah pemerintahan Susilo Bambang Yudhoyono bersikap keras dengan melarang kehadiran ISIS dan para pendukungnya. Sejak sikap yang tegas inilah, seluruh elemen pemerintahan dan badan keamanan Indonesia melakukan tindakan untuk menutup dan menahan sejumlah orang yang diduga membawa atribut ISIS dan menyebarkan paham ini. Lebih jauh dari itu pemerintah Indonesia melakukan aksi anti terorisme di Indonesia.

Langkah yang diambil pemerintah Indonesia dalam menangani kampanye ISIS antara lain dengan program deradikalisasi. Namun belakangan muncul pendapat bahwa program ini tidak memenuhi tujuannya, seperti salah satu gambaran yang dimuat Kompas

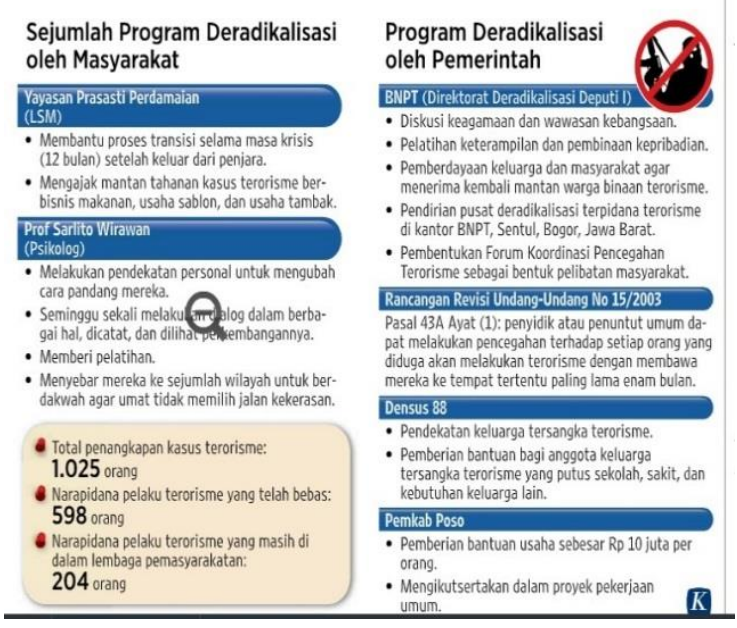

(Kompas, 21 Juli 2015).

\section{Konseptualisasi}

Problem yang muncul dengan kampanye skala dunia ISIS ini sudah ditanggapi oleh Amerika Serikat secara langsung di wilayah ISIS di Irak dan Suriah dengan berbagai operasi militer. Namun untuk memahami bagaimana ISIS muncul di Timur Tengah, causal lopp berikut dapat menjelaskan sejumlah kaitan antara kebijakan Amerika Serikat 
menyerbu Irak untuk menegakkan pemerintahan demokratis dengan munculnya ISIS (Jamie P Monat, 2015: 36-49).
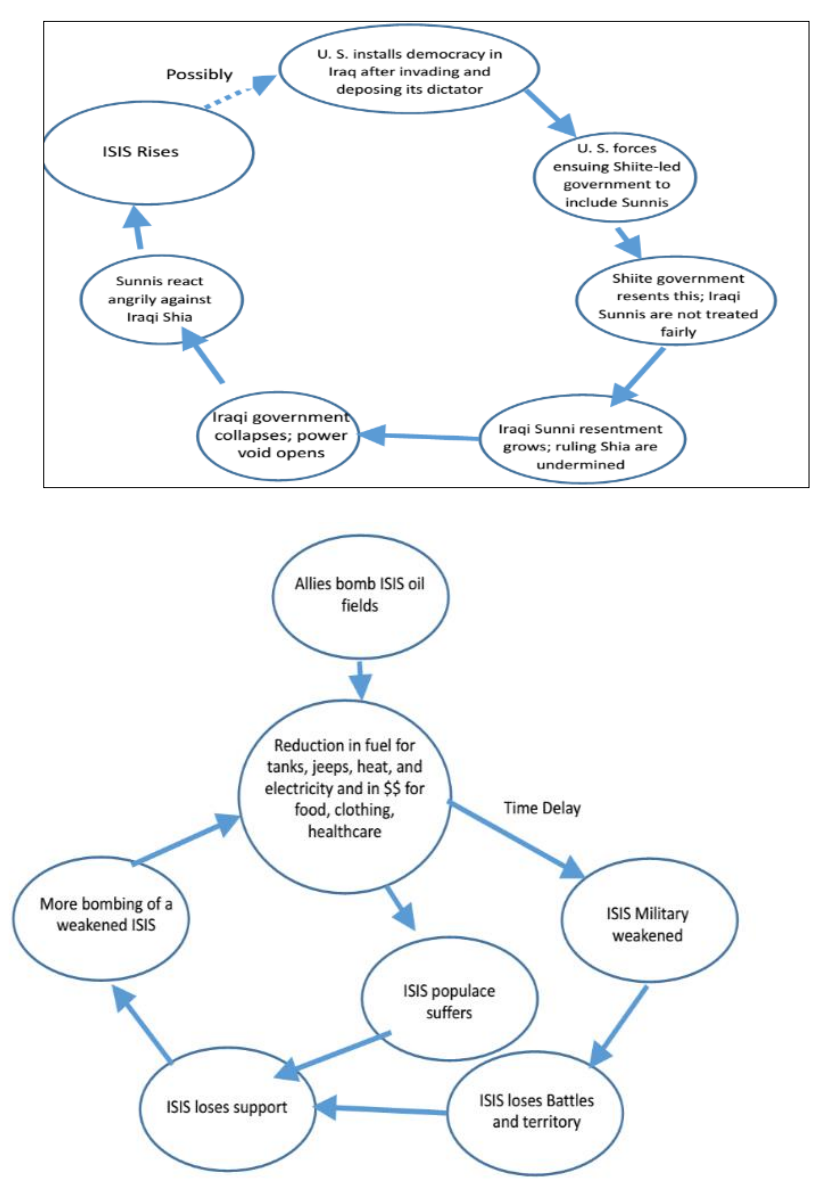

Untuk menghadapi ISIS di Irak dan Suriah ini Amerika Serikat dan sekutunya melakukan langkah untuk menghancurkan infrastruktur yang dikuasai ISIS. Dengan menghancurkan infrastruktur ISIS ini maka ISIS akan kehilangan wilayah dan kehilangan dukungan yang selanjutnya akan melemahkan dan menghilangkan ISIS (Jamie P Monat, 2015: 36-49).

Solusi menyeluruh dari ISIS ini dapat dilihat dari gambar berikutnya dimana mulai dari rekrutmen, perebutan wilayah serta bagaimana menghancurkan infrastruktur sehingga ISIS tidak lagi memiliki kekuatan financial untuk menopangnya dirinya termasuk untuk gerakan rekrutmen internasional seperti di Indonesia (Jamie P Monat, 2015: 36-49). Diagram berikut menunjukkan bahwa operasi yang dilakukan tidak hanya terbatas pada pelemahan secara militer tetapi juga secara keseluruhan termasuk dalam mengurangi penunjang ISIS berupa dana yang digunakan dalam menggaji milisi asing, menjalankan pemerintahannya termasuk dalam operasi militer dan penyerangan terhadap kelompok yang yang targetnya. Dana itu juga diperlukan untuk menangkis serangan Amerika dan sekutunya. 


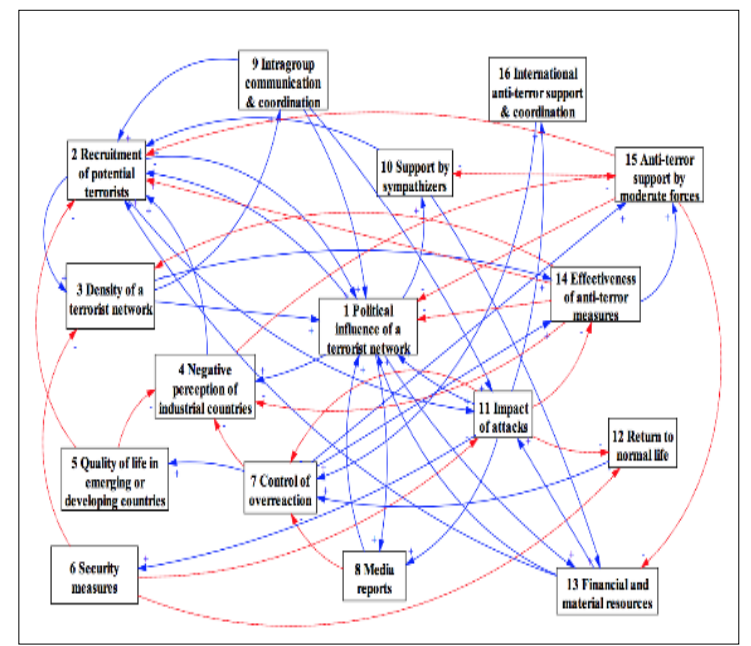

Sedangkan model dalam dalam menghadapi aksi terorisme ini dapat digambarkan sebagai berikut dimana keseluruhan aspek disinggung (Jamie $\mathrm{P}$ Monat, 2015: 36-49). Dalam causal loop diagram tampak bahwa rekrutmen merupakan salah satu aspek untuk mempertahankan keberlanjutan sebuah gerakan radikal seperti ISIS. Rekrutmen ini akan menambah jumlah terois dan juga meningkatkan daya pengaruh politiknya. Rekrutmen yang tinggi juga akan meningkatkan daya serangan ISIS di berbagai wilayah. Sedangkan operasi anti terror akan menurunkan daya rekrutmen ISIS. Semakin baik efektivitas anti teror juga akan mengurangi kemampuan rekrutmen (Schoenenberger, Wicki, dan Beck, 2014).

\section{Formulasi Model}

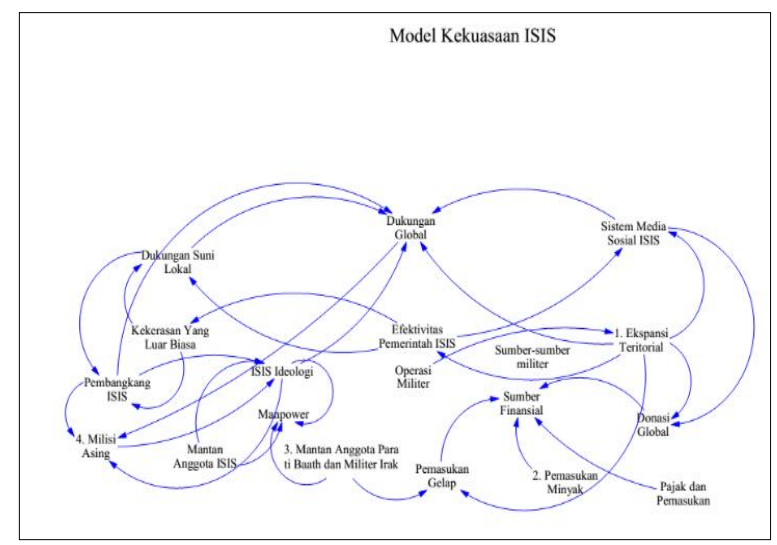

Diagram mengenai elemen penting kekusaan ISIS dapat dilihat sebagai berikut (Watts, 2014):

Elemen dari System Dynamics adalah yakni Feedback (causal loop), Stock (level) and Flow (rate), Delay, Non-linearity (Tasrif, 2016). Dari pendekatan system dynamics ini dapat disebut stock and flow yakni Pendukung ISIS di Indonesia dan Terorisme. Bertambahnya pendukung ISIS akan meningkatkan tindak terorisme di Indonesia dan juga di wilayah luar Indonesia. Semakin rendahnya pendukung ISIS makan akan semaki sempit ruang gerak mereka dalam melakukan aksi terorisme. Namun kebijakan yang dilakukan di Indonesia juga sangat tergantung kepada perkembangan yang berlangsung di pusat kekuasaan ISIS. Jika kekuatan mereka melemah di Irak dan Suriah maka kampanye juga akan melemah yang akibatnya akan mengurangi aksi terorisme di 
Indonesia. Sebaliknya lemahnya ISIS akan memperkuat kebijakan pemerintah Indonesia untuk menangkal ISIS.

\section{Keterangan variabel dalam}

\section{diagram:}

- $\quad$ Pendukung ISIS : Jumlah pendukung ISIS naik turun akibat kampanye rekrutmen.

- Kampanya Rekrutmen ISIS: Kampanye untuk merekrut pendukung ISIS di Indonesia.

- Cyber Jihad: kampanye rekrutmen ISIS: kampanye dari ISIS di Suriah dan Irak melalui media sosial, internet.

- Kelompok Radikal Indonesia: kelompok yang menerima rekrutmen dari ISIS.

- Waktu Rekrutmen: lamanya rekrutmen ISIS.

- Keluar dari ISIS: pendukung ISIS keluar dari ISIS karena operasi pencegaham ISIS.

- Kematian pendukung ISIS: pendukung ISIS yang mati karena operasi pencegahan.

- Perubahan sikap: Pendukung ISIS yang berubah sikap menjadi aktif mendukung terorisme.

- Bergabung dengan ISIS di Irak dan Suriah: Pendukung ISIS yang bergabung ke Irak dan Suriah.
- Penumpasan aksi terorisme: tindakan pemerintah yang berkuasa untuk menumpas terorisme

- Program pencegahan terrorism: program yang dilakukan melalui operasi keamanan seperti Densus 88

- Program deradikalisasi: program pemerintah yang dilakukan untuk kampanye deradikalisasi

- Operasi Penumpasan ISIS: Operasi yang dilakukan aparat keamanan dalam menumpas aksi terorisme

- Kematian pendukung ISIS: kematian pendukung karena operasi keamanan

- Waktu keluar: masa dimana pendukung ISIS keluar karena

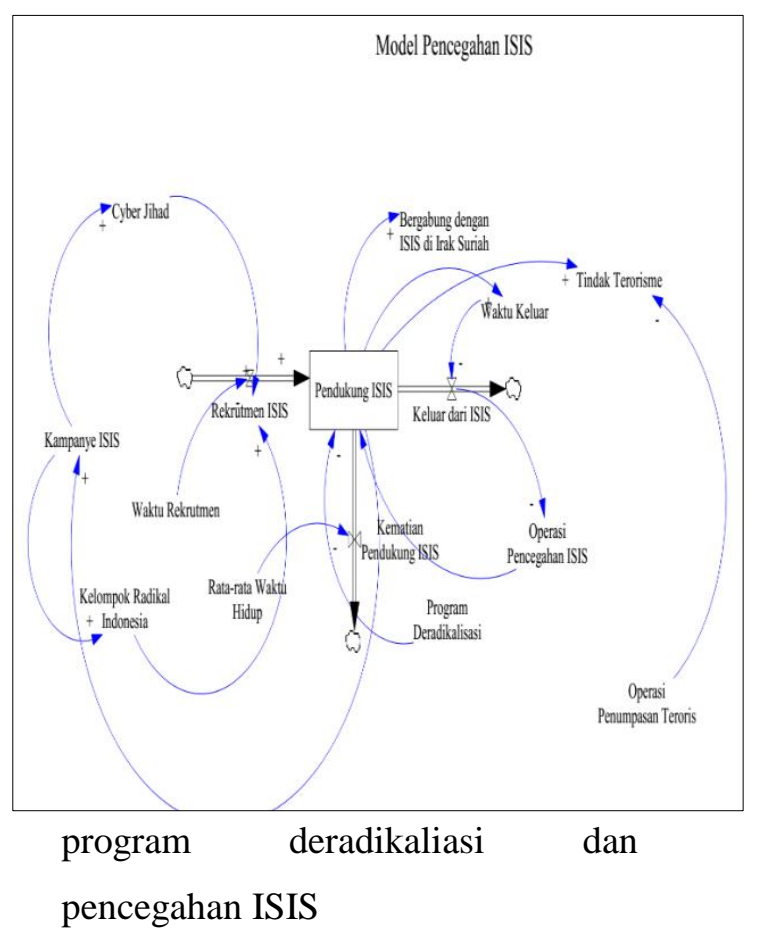



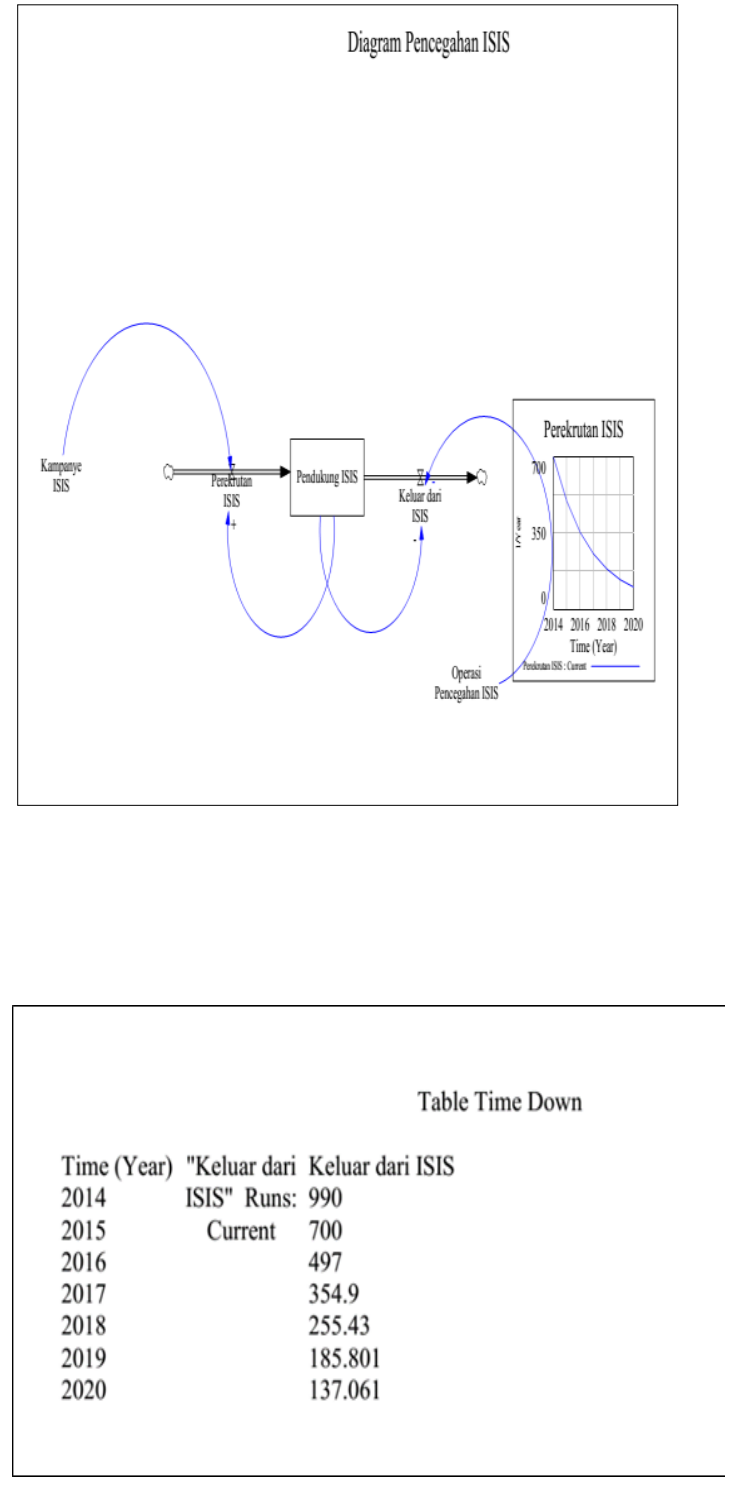

Kalau pencegahan dilakukan secara konsisten oleh pemerintah Indonesia dengan operasi anti ISIS maka jumlah pendukung ISIS akan berkurang dari tahun ke tahun. Namun keberhasilan program mencegah rekrutmen ISIS masih tergantung sejumlah variabel termasuk kekuatan ISIS di Timur Tengah.

\section{Penutup}

Kampanye rekrutmen ISIS yang dilakukan melalui media sosial dan internet harus dapat dibendung jangan sampai meluas ke berbagai kalangan masyarakat. Pembendungan itu bisa dilakukan dengan cara operasi anti terorisme atau dengan kegiatan deradikalisasi. Jaringan internet dan media social dibatasi untuk content yang berisi ajakan rekrutmen ISIS.

Kampanye rekrutmen ISIS secara langsung harus dibatasi dan dikurangi dengan melakukan operasi langsung anti terorisme dan juga program deradikalisasi. Program menghadapi kampanye rekrutmen ini tidak bisa hanya dilakukan dengan operasi anti terorisme tetapi juga pendekaan social ekonomi dan pendidikan keagamaan.

Keberhasilan Indonesia dalam mencegah berkembangnya dampak kampanye ISIS tergantung dari perkembangan ISIS di Timur Tengah. Jika ISIS melemah maka akan berdampak terhadap kekuatan kampanye ISIS di Indonesia yang akan menguntungkan pemerintah. 


\section{DAFTAR PUSTAKA}

Alkhouri, Laith, Alex Kassier and Allison Nixon. (2015). Hacking for ISIS: The Emergent Factor Cyber Threat Landscape. New York: Flashpoint.

Badan Nasional Penanggulangan Terorisme. (2015). Waspada ISIS. Jakarta: Badan NasionalPenanggulangan Terorisme.

Bell, Anna Scott. (2015). "ISIS and Islamic Radicalization in Southeast Asia: An Interview with Mohamed Nawab Mohamed

Osman."Georgetown Jounal of Asian Affairs.

Bunzel, Cole. (2015) .From Paper State to Caliphate: The Ideologi of the Islamic State. Washington : Brooking Institution.

Clauset, A. and Gleditsch, K.S., (2012). "The Developmental Dynamics of Terrorist Organizations. “ PloS one, 7(11), p.e48633.

D’Souza, Kirk. (2016). Jakarta Terror Attack. New York: International Institute ForCounter Terrorism.

De Mena, Mar Pajares. (2011). "Terrorist Incident and Counter Terrorist Policies: A Sytem Dynamics Model." Anales de Estudios Economicos y Empersariales. Vol XXI. 227243.

Dyer, Charles H. and Mark Tobey. (2015). The Isis Crisis.
Chicago:

Moody

Publishers.Friedland, Elliot.20

15.The Islamic State. Clarion Project.

Galamas, Francisco. (2015). "Terrorism in Indonesia: An Overview.@Documento de Investigation del Institute Espanl de Estudos Estrategicos.

Gunaratna, Rohan.(2016). Global Terrorism in 2016." UNISCI Journal, No 40,January 2016.

Gutfraind, A., (2009). "Understanding Terrorist Organizations with a Dynamic Model." Studies in Conflict \& Terrorism, 32(1), pp.45-59.

Hanson, Fergus. (2015). Countering ISIS in Southeast Asia: The case for an ICT Offensive. Perth: USAsia Centre.

Hamid, Ahmad Fauzi Abdul. (2016). ISIS in Southeast Asia : Internalized Wahhabism is a Major Factor. Singapore: ISEAS.

Hashim, Ahmed S. (2015). The Impact of The Islamic State in Asia. Singapore: RSiS.n

IPAC. (2015). Changing Patterns of Support for Violent Extremism in Indonesia.

IPAC. (2014). The Evolution of ISIS in Indonesia. IPAC Report No. 13.

Jones, Sidney. (2015). "ISIS in Indonesia." Southeast Asian Affairs $2015.1 \quad$ (2015): 154163. 
Konrad Adenauer Stiftung. (2015). From The Desert to World of Cities: The New Terrorism.Singapore: Konrad Adenauer Stiftung.

Lang, Hardin and Muath Al Wari. (2016). The Flow of Foreign Fighters to the IslamicState.Washington:

Center for American Progress.

Lewis, Jessica Mc Fate and Harleen Gambhir and Evan Sterling. (2014). ISIS'S Global Messaging Strategy Fact Sheet. New York: Institute for Study of War.

Monat, Jamie P. (2015). "Thomas F Gannon. 2015. Using Systems Thinking toAnalyze ISIS." American Journal of System Science 2015, 4 (2):36-49.

Mubarak, M. Zaki. (2015). "Dari NII ke ISIS: Transformasi Ideologi dan Gerakan dalam Islam Radikal di Indonesia Kontemporer."Jurnal Episteme, Vol. 10. No1, Juni 2015.

Nuraniyah, Navhat. (2015). How ISIS Charmed the New Generation of Indonesian Militants. Singapore: Center of Excellence for National Security.

Patrick. (2015). The Rise of Islamic State ISIS and New Sunni Revolution. London: Verso.

Paté-Cornell, E. and Guikema, S.,( 2002). Probabilistic Modeling of Terrorist threats: A systems analysis approach to setting priorities among countermeasures. Military

Operations Research, 7(4), pp.5-23.

Plethi, Crethi.(2015). ISIS's Ideologi and Vision, and their Implementation.

Philips, George, ISIS in Indonesia: 500 Recurits and Counting, dalam

http://www.gatestoneinstitut e.org/6002/isis-indonesia.

Razi, Fahrur. Global Salafi Jihadi

Tantangan Masa Depan

Islam Indonesian.

Dalam https://xa.yimg.com/kq/gr oups/19587790/2111190744/name/ Global+Salafism-

Ust+Fahrur+Rozi.docx.

Ryan, Michael. (2015). ISIS: The Terrorist Group That Would Be a State. Case study.Newport, RI: US Naval War College, Center on Irregular Warfare and Armed Groups.

Samuel, Thomas Koruth. (2016). Radicalistion in Southeast Asia: A Slected Case Study of Daesh in Indonesia, Malaysia and The Philippines. Kuala Lumpur: Search.

Sinar Harapan. (2015) .ISIS Indonesia Makin Membahayakan.

Sudiman, Saiful Alam Shah. (2016). Indonesia's Response to Jakarta Attacks: New Strategy to Curb ISIS' Influence. Singapore: RSIS.

Schulze. Kirsten E.( 2016). The Jakarta Attack and The Islamic State Threat to Indonesia.Dalam CTC 
Sentinel Volume 9, Issue 1, January 2016. New York: CTC Sentinel.

S. Rajaratnam School of International Studies. "Counter Terrorist Trends and Analysis. "Journal of The International Centre for Political Violence and Terrorism Research, Volume 7 Issue 1, JanuaryFebruary 2016. Singapore: RSIS.

Tomsa, Dirk.(2016). The Jakarta Terror Attack and its Implications for Indonesian and Regional Security. Singapore: ISEAS.

The Soufan Group. (2015). Foreign Fighters: An Updated Assessment of the Flow of Foreign Fighters int Syria and Iraq. New York: The Soufan Group.

USAID. (2016). Indonesian and Malaysian Support for the Islamic State. Arlington: USAID.

Qulliam. (2015). Detailed Analysis of Islamic State Propaganda Video: Although the Disbelivers Dislike it. New York: TRAC.

Wakeland, Wayne.(2005). "Dynamic Models of a Counterterrorism Strategic InfluenceCampaign.”

Watts, John T. (2016). "Hearing on ISIS in Pacific: Assesing Terrorism in Southeast Asia and the Threat to Homeland Security". Altantic Council: Brent Scowcroft Center of International Security.
Weiss, Michael and Hassan Hassan. (2015). ISIS: Inside the Army of Terror. New York: Regan Arts.

Watts, John T.(2016). Hearing on ISIS in Pacific: Assesing Terrorism in Southeast Asia and the Threat to Homeland Security. Altantic Council: Brent Scowcroft Center of International Security.

Wibisono, Ali Abdullah. (2016). ISIS and Indonesia's Response to Terrorism.Washington: The Washington Review. 